\title{
“É POSSÍVEL CONTROLAR A MULTIDÃO?" LIBÂNIO EM DEFESA de JULIANO E CONTRA A POPULAÇÃo dE ANTIOQUIA (SÉC. IV)
}

Gilvan Ventura da Silva ${ }^{1}$

\begin{abstract}
Resumo
Quando tratamos do emprego do humor e do deboche como mecanismos de resposta da população urbana ao desempenho das autoridades romanas, um caso emblemático de estranhamento entre súditos e imperador é aquele que ocorre entre 362 e 363, em Antioquia, durante a estadia de Juliano na cidade. Esse estranhamento foi tão intenso que acarretou, num primeiro momento, a elaboração de uma obra no mínimo desconcertante como o Misopógon, texto satírico no qual Juliano tece duras críticas ao modus vivendi dos habitantes da cidade. Na sequência, como desdobramento do episódio, vem à luz dois discursos de Libânio, um deles intitulado Aos antioquenos, sobre a ira do imperador (Or. XVI) e o outro, Embaixada a Juliano (Or. XV). Ambos os discursos buscavam reverter a difícil situação na qual se encontrava Antioquia, alvo da cólera do soberano. Nesse artigo, pretendemos explorar os argumentos de Libânio sobre a controvérsia envolvendo Juliano e os antioquenos a fim de demonstrar como o sofista se encontrava comprometido com a proposta de reforma da pólis idealizada pelo imperador.
\end{abstract}

\section{Palavras-Chave}

Antiguidade Tardia; Antioquia; Libânio; Juliano; Multidão.

\footnotetext{
${ }^{1}$ Professor Titular, Universidade Federal do Espírito Santo, Vitória, Brasil. E-mail: gilventura@uol.com.br
} 


\begin{abstract}
Regarding the recourse to humor and mockery as response mechanisms of a city's population to the performance of imperial power, an emblematic case of estrangement between a ruler and his subjects occurred in 362-363 during Emperor Julian's stay in the city of Antioch. Their estrangement was so intense that it led to the writing of an at least disconcerting work such as the Misopogon, a satirical text in which Julian harshly criticizes the modus vivendi of Antioch's inhabitants. As a result of this episode, two discourses written by Libanius, To Antiochians, on the Emperor's anger (Oration 16), and The embassy to Julian (Oration 15), attempt to reverse Antioch's difficult situation in face of Julian's anger. This article explores Libanius' reasoning about the controversy involving Julian and Antioch's inhabitants, in order to demonstrate how the sophist was committed to the emperor's proposal of reforming the polis.
\end{abstract}

\title{
Keywords
}

Late Antiquity; Antioch; Libanius; Julian; Crowd. 
Antioquia, na segunda metade do século IV, era considerada a mais importante cidade do Oriente após Constantinopla. Distinguindo-se pela sua diversidade étnica, cultural e religiosa, a então metrópole da Síria Coele abrigava à época uma população em contínuo crescimento devido à migração de indivíduos provenientes da khora ou mesmo de outras regiões da Síria-Palestina e da Ásia Menor, que amiúde se dirigiam à cidade em busca de melhores condições de vida ou com o objetivo de estudar, tendo em vista o prestígio alcançado pelo didaskaleion de Libânio (Saliou, 2000: 809). Antioquia revelava-se assim uma cidade vibrante que nutria um entusiasmo particular pelos festivais, jogos e espetáculos, com destaque para a festa das Calendas de Janeiro, que assinalava a chegada do Ano Novo, e para o festival da Maiuma, em louvor a Dioniso e Afrodite, celebrado a cada três anos por um período de trinta dias. ${ }^{2}$ Ao mesmo tempo, a cristianização seguia em curso mediante o esforço de líderes religiosos como Melécio, Flaviano e João Crisóstomo, que se empenhavam em reformar as crenças e costumes da pólis. Dentre o conjunto de estratégias implementadas a fim de reduzir a atração exercida pelos festivais pagãos, contava-se a instituição de um extenso calendário de comemorações em honra aos mártires e santos. Todavia, por meio das homilias de João Crisóstomo percebemos o quanto o ethos festivo se encontrava arraigado na população, pois o pregador não poupa críticas aos devotos que, no decorrer da pompé, da procissão solene em louvor aos mártires, costumavam reproduzir a mesma conduta verificada durante as festas das Calendas e da Maiuma, agrupando-se em cortejos dionisíacos e entregando-se à bebida, ao canto e à dança (Soler, 2010: 278). ${ }^{3}$ Por fim, em virtude da presença, na cidade, de uma ativa comunidade judaica, Antioquia era palco também de cerimônias que, tendo como epicentro a sinagoga, costumavam alcançar as ruas, como vemos no caso do Rosh-Ha-Shanah, o Ano Novo judaico; e do Sukkot, a Festa dos Tabernáculos, quando o soar das trombetas e a euforia dos judeus contagiavam os passantes (Silva, 2011: 49).

\footnotetext{
2 Uma antiga tradição transmitida por Malalas, um cronógrafo bizantino do século VI, situava a Maiuma em maio, mas pesquisas recentes indicam outubro como o mês mais provável da festa (Soler, 2006: 10).

${ }^{3}$ Um dos lugares mais atacados por João, além do teatro e da sinagoga, é a ágora, certamente aquela localizada em Epifânia, um bairro ao que tudo leva a crer construído por Antíoco IV Epifânio (175-164 a.C.). Em suas imediações se situavam a avenida das colunatas e o Fórum de Valente (Downey, 1961: 621). Sabemos que para alcançar uma das igrejas nas quais oficiava, João Crisóstomo era obrigado a cruzar a ágora (Mayer, 2012: 84), entrando assim em contato direto com a população, o que lhe fornecia motivo suficiente não apenas para condenar os festivais e demais atividades cívicas, mas também para censurar os membros da sua congregação por adotarem, à vista de todos, uma conduta que os equiparava aos pagãos.
} 
Essa exuberância festiva de Antioquia, que se traduzia numa rede de relações de sociabilidade capaz de congregar, pelas ruas e praças, conhecidos e desconhecidos, estrangeiros e residentes, cristãos, pagãos e judeus derivava de uma longa tradição segundo a qual a vida, na pólis, comportava uma dimensão pública que não raro se sobrepunha à dimensão privada, realidade que as lideranças episcopais do período tardio conheciam bastante bem e que tentaram a todo custo reverter ao investirem num discurso que priorizava o oikos, o recinto familiar, e a igreja como loca privilegiados de exercício das virtudes cristãs. ${ }^{4}$ Sob essa perspectiva, Antioquia, mesmo na fase pós-clássica, conservava a ênfase na esfera pública, coletiva, da existência que tanto havia animado a vida urbana do Império Romano na fase anterior. De fato, o seu plano urbanístico, caracterizado por um percurso amplo e monumental - a avenida das colunatas, repleta de pórticos - e pontos focais adjacentes (ágora de Epifânia, Fórum de Valente) acentuava e favorecia a capacidade de integração entre os habitantes, que se reuniam para negociar, conversar, divertir-se e manifestar seu desagrado diante dos rumos da política imperial, o que dava ensejo a protestos e sedições periódicas. Mediante o encontro regular de residentes e visitantes nos banhos, no teatro, no hipódromo, nos pórticos, nas igrejas e sinagogas, na ágora, nas tavernas e portas da cidade constituía-se a tessitura das relações sociais, ocorrendo uma troca contínua de informações que, segundo Petit (1955: 221), propiciava a formação de uma "opinião pública", não obstante o sentido um tanto ou quanto moderno da expressão. ${ }^{5}$

4 No Império Romano, a distinção entre público e privado não se pautava pela clivagem cartesiana que hoje estabelecemos - ou tentamos estabelecer - entre assuntos de foro íntimo e assuntos de interesse coletivo. De acordo com Winterling (2009), num estudo esclarecedor sobre o significado das categorias "público" e "privado" na sociedade imperial, muito embora o léxico registre uma distinção entre a res publica, a arena da comunidade cívica, e a domus, a esfera doméstica, estes dois setores frequentemente se sobrepunham, de maneira que as residências, em especial as da aristocracia, não raro desempenhavam funções de natureza política, ao passo que assuntos a princípio de interesse tão somente familiar poderiam de um momento para o outro se tornar objeto de apreciação pública. Além disso, em face da exiguidade de aposentos individuais na maioria das habitações romanas, sendo o quarto particular um privilégio reservado aos mais ricos, os indivíduos eram compelidos a se integrar nas redes de socialização que tinham a rua como suporte, vivendo nos mercados, tavernas e banheiros públicos uma existência em contato estreito com seus contemporâneos e com eles compartilhando valores, aspirações, ideias e sentimentos (Funari, 2003, p. 89; Leguay, 1997, p. 23).

5 A ideia de uma "opinião pública" não era completamente estranha à Antiguidade. Os romanos, por exemplo, denominavam opinio o juízo que determinado público fazia sobre certos assuntos. Cícero e Suetônio, por sua vez, se referem, em seus escritos, à existência de uma popularis opinio e de uma comunis opinio (Lima Neto, 2016: 209). 
Seja como for, o importante é registrar que muito embora a relação dos antioquenos com as autoridades imperiais fosse, do ponto de vista institucional, mediada pela boulé, o conselho encarregado da administração da pólis, em certos casos essa relação assumia contornos mais diretos, menos mediatizados, como vemos ocorrer nas solenidades de recepção e despedida dos imperadores e de seus representantes, quando a multidão, tendo à frente os cidadãos mais proeminentes, se aglomerava nas portas da cidade com demonstrações de júbilo ou de pesar, conforme o caso. Como salienta Liebeschuetz (1972: 209), as aclamações dirigidas às autoridades públicas eram, sob o Império, um componente indispensável do jogo político, pois todo detentor de um cargo de alguma relevância nutria a expectativa de ser recepcionado com gritos pela população sempre que adentrasse o teatro ou se deslocasse pelas ruas, tratando essas manifestações como "genuína evidência do sentimento dos súditos, e mostrando-se preocupado se os apupos não fossem ruidosos o suficiente". Decerto, um governador de província recebido, no teatro, em completo silêncio não seria um bom sinal. Evidência substantiva acerca da importância que o Estado romano conferia à atitude dos espectadores na presença dos delegados imperiais é uma lei de Constantino (C. Th., I, 16, 6), datada de novembro de 331, na qual o imperador reconhece a todos o direito de saudar abertamente os "mais justos e vigilantes juízes", ou seja, de exprimir sem reservas ou censura a satisfação - ou mesmo a insatisfação - com o desempenho dos governadores de província, constituindo tais saudações um critério a ser levado em conta para efeitos de promoção na carreira administrativa.

Além das aclamações, encenadas todas as vezes em que as autoridades imperiais estivessem em contato direto com a população, seja na corte de justiça, no teatro, no hipódromo ou mesmo nas ruas e praças, os citadinos poderiam exprimir, mediante o deboche e a galhofa, sua opinião acerca da maneira pela qual eram governados, fazendo circular panfletos ou entoando cantigas (asmata) e versos satíricos (anapestos) contendo críticas mordazes ao governo (Ballabriga, 2009: 67), em especial por ocasião das Saturnálias, em dezembro, ou do festival das Calendas, no início de janeiro. ${ }^{6}$ Tanto as Saturnálias quanto as Calendas eram consideradas

Como bem observa Farge (2011: 87), a população não permanece inerte diante das manobras do governo, mas elabora e retransmite, com seus próprios meios, sua avaliação acerca das questões públicas de seu tempo, mesmo que suas declarações sejam denegadas "pelo poder como sendo 'insensatas' ou frequentemente qualificadas de instintivas demais para serem razoáveis".

${ }^{6}$ Nas cidades do Império, era comum que as críticas de teor político fossem difundidas por intermédio de um conjunto de suportes: grafites, cartazes e anúncios afixados em locais visíveis (como o pedestal das estátuas), tabletes de cera e papiros que passavam de mão em mão, composições orais. Esses versos, libelos e inscrições eram todos meios 
festas de transgressão, de subversão temporária dos códigos que regiam a ordem social, quando as normas hierárquicas poderiam ser rompidas sem maiores riscos para os foliões, o que permitia à população exercer a licentia ou parresia, a fala franca dirigida aos representantes do poder, não raro incluindo o próprio imperador (Hawkins, 2012: 161). Sabemos que, em algumas cidades do Oriente, as chacotas pronunciadas oralmente poderiam ser acompanhadas por música e por movimentos corporais frenéticos, o que certamente potencializava a sua capacidade corrosiva. Em Antioquia, nos momentos de alegria e descontração, era comum a formação de komoi, cortejos dionisíacos nos quais participantes de ambos os sexos se exibiam sob o efeito do vinho. Muito popular também eram os choroi, coros de foliões que, agrupados em círculos compostos por homens, mulheres e jovens, cantavam e dançavam pelas ruas e praças da cidade, especialmente à noite (Soler, 1997: 327-8). As cantigas entoadas nessas ocasiões poderiam encerrar um teor político, pois os komoi e choroi costumavam ser empregados como instrumentos de escárnio contra as autoridades públicas. Embora sem identificação de autoria e marcadas por um inequívoco tom satírico, essas críticas não devem, em absoluto, ser encaradas como algo periférico ou ineficaz quando se trata de investigar o nível de comunicação mantido entre governo e população, na medida em que, por meio das demonstrações coletivas de deboche, é possível recuperar não apenas os temas ou assuntos potencialmente significativos para a coletividade, o grau de popularidade desta ou daquela decisão, mas também a representação que se fazia dos governantes. Mais do que isso, seria enganoso supor que os envolvidos em episódios de aberta zombaria fossem sempre levados a ignorar aquilo que a seu respeito se dizia em praça pública, adotando assim uma atitude distante e superior ao serem confrontados pela multidão, à qual amiúde se atribuía um comportamento sórdido, licencioso ou pueril.

Em se tratando do emprego do humor e do deboche como mecanismos de resposta da população urbana ao desempenho das autoridades romanas, um caso emblemático de estranhamento entre súditos e imperador é aquele que ocorre entre 362 e 363, em Antioquia, durante a estadia de Juliano na cidade. Esse estranhamento foi tão intenso que acarretou, num primeiro momento, a elaboração de uma obra no mínimo desconcertante como o Misopógon, um texto satírico no qual Juliano tece duras críticas ao modus vivendi dos antioquenos. Na sequência, como desdobramento do episódio, vem à luz dois discursos de Libânio, um deles intitulado Aos antioquenos, sobre a ira do imperador (Or. XVI) e o

de se exprimir "um descontentamento, uma vingança, uma resposta anônima e clandestina a um ato efetuado por uma pessoa no poder, uma circunstância tida como injusta ou imoral, e insuportável" (Crogiez, 1997: 227). 
outro, Embaixada a Juliano (Or. XV). Ambos os discursos buscavam reverter a difícil situação na qual se encontrava Antioquia, alvo da cólera do soberano.

Juliano permaneceu em Antioquia cerca de oito meses, entre julho de 362 e março de 363, após uma breve passagem por Constantinopla, onde celebrou as exéquias de Constâncio II, morto em novembro de 361. Sua entrada solene na cidade ocorreu em 18 de julho, no segundo dia do festival de Adônis, quando se pranteava a morte da divindade, o que mais tarde foi reportado por Amiano Marcelino (XXII, 9, 15) como um mau presságio. Muito embora Antioquia, àquela altura, atravessasse uma grave crise de abastecimento, resultado de uma longa estiagem que havia arruinado a colheita do trigo (Liebeschuetz, 1972: 126 e ss.), a multidão apressou-se em acolhê-lo às portas da cidade, dispensando-lhe honrarias como se o imperador fosse uma espécie de divindade (Am. Marc., XXII, 9, 14). Logo depois, Juliano voltou a ser bem recebido pelo público reunido no teatro para saudá-lo. Em pouco tempo, no entanto, sua relação com a cidade tornou-se conflituosa, e isso por diversos motivos. Em primeiro lugar, seus esforços para contornar a crise foram vãos, pois o trigo importado de Cálcis, de Hierápolis e do Egito, vendido a preço fixo, era adquirido pelos atravessadores com vistas à especulação. Os comerciantes, culpando os produtores agrícolas pela carestia, decidiram cruzar os braços, em protesto. O tabelamento do preço do pão, expediente destinado a conferir algum alívio à população urbana, não surtiu o efeito desejado, pois os camponeses afluíram em massa à cidade para se beneficiar da medida (Bowersock, 1997: 100). Já o aquartelamento de um extenso contingente de soldados em Antioquia aumentava a demanda por víveres. Por fim, a campanha da Pérsia era tida como um erro de estratégia, carecendo, portanto, de apoio popular (Downey, 1961: 390 e ss.). À parte todas essas variáveis de ordem econômica e militar, bastante influentes por sinal, é necessário atentar para o fato de que o "ruído" entre Juliano e os antioquenos foi agravado também pela política religiosa do imperador, que gerou uma série de atritos, não apenas com os adeptos do cristianismo, como seria de se esperar, mas igualmente com os pagãos (Kleinaman, 2008-2009: 69).

Durante o tempo em que residiu em Antioquia, Juliano dedicou-se a uma autêntica peregrinação pelos templos e santuários em sinal de reverência às divindades cívicas, dentre as quais se distinguiam Zeus, Deméter, Hermes, Pan, Ares, Calíope, Apolo, Ísis e a Tyché. Uma peculiaridade da devoção de Juliano era o seu apego aos sacrifícios sangrentos, com o abate de um grande número de vítimas prontamente consumidas pelos soldados de sua comitiva (Am. Marc., XXII, 12, 6), atitude um tanto ou 
quanto acintosa diante de uma crise de abastecimento em curso. $\mathrm{O}$ palácio imperial da ilha do Orontes, por sua vez, foi convertido num santuário, erigindo-se altares nos jardins, sob as árvores, onde $\mathrm{o}$ imperador poderia oficiar os sacrifícios com maior comodidade (Downey, 1961: 384)). Crítico contumaz dos jogos, dos mimos e pantomimas, Juliano se afasta deliberadamente do teatro e do anfiteatro, proibindo inclusive que os sacerdotes pagãos compareçam aos espetáculos ou recebam a visita de atores, aurigas e dançarinos (Ep. 89b, 304). Um traço peculiar de Antioquia que causava profunda irritação ao imperador era o apreço dos habitantes pela dança e pelos dançarinos, motivo pelo qual os repreende, em mais de uma oportunidade, por dançarem o cordax, uma dança lasciva em louvor a Ártemis, que julgava obscena (Jul., Misopógon, 20; 30). Agindo com singular audácia, decide suspender a subvenção imperial à Maiuma, ao que tudo indica com a intenção de resguardar a moralidade pública, já que a festa era famosa por seus ritos orgiásticos (Soler, 2006: 39). Inclinado a uma postura rigorista e altaneira, Juliano se apresenta, na cidade, como um filósofo, evitando o contato com a população nos espaços de lazer, censurando suas modalidades de entretenimento e acusando-a de indiferença para com os deuses. Desafiados, os antioquenos não tardam a reagir.

De acordo com Gleason (1986: 108), no início de janeiro de 363, quando da comemoração das Calendas, o desconforto da população com Juliano teria se tornado insustentável, 7 pois a festa, em virtude do seu caráter jocoso, forneceu à população o pretexto para exercitar amplamente sua verve satírica, sendo o imperador comparado a um macaco, a um anão, a um bode barbado e mesmo a um victimarius, um açougueiro, devido à pletora de sacrifícios que promoveu (Am. Marc., XXII, 14, 3). Não obstante a indignação pelo ultraje sofrido, Juliano evitou o uso da força, preferindo responder aos insultos mediante a redação do Misopógon, obra na qual empregava a ironia para justificar suas ações, ao mesmo tempo em que censurava asperamente os antioquenos pela sua leviandade e indisciplina. O Misopógon, em tradução literal, o "inimigo da barba", foi

\footnotetext{
7 Muito embora Van Hoof \& Van Nuffelen (2011) não concordem com a hipótese de Gleason (1986) segundo a qual a redação do Misopógon estaria conectada com as festividades das Calendas de 363, argumentando que muito antes disso já circulavam pelas ruas de Antioquia críticas a Juliano, não resta dúvida que as Calendas, pelo fato de darem ensejo a manifestações satíricas contra as autoridades públicas, representavam uma oportunidade bastante propícia para o aumento da tensão entre Juliano e a população da cidade. Nesse sentido, não vemos maior dificuldade em admitir que Libânio (Or. XVI, 36), ao mencionar a existência, em Antioquia, de festivais caracterizados pelo ridículo, no decorrer dos quais os antioquenos desferiram rudes ataques contra Juliano, esteja se referindo ao festival das Calendas de Janeiro, como sustenta Gleason.
} 
composto entre a segunda quinzena de janeiro e o mês de fevereiro de 363, num momento em que o soberano se preparava para partir em campanha contra o Império Persa. O título alude à barba de filósofo ostentada por Juliano que tanto desconforto causava aos citadinos. A fim de conferir maior publicidade à obra, o Misopógon foi afixado no Tetrapilo dos Elefantes, arco triunfal que suportava, muito provavelmente, uma biga ou quadriga puxada por tais mamíferos. O monumento encontravase instalado no centro da ilha formada pelo Orontes, na interseção das quatro ruas de pórticos, próximo ao palácio imperial, local bastante frequentado por residentes e visitantes (Saliou, 2009: 240-241).

Em 5 de março de 363, logo após a divulgação do Misopógon, Juliano deixa Antioquia para dar combate aos Sassânida. Sua partida, no entanto, prenunciava tempos sombrios para a cidade. A esse respeito, podia-se evocar o exemplo de Cesareia da Capadócia, onde os cristãos, logo após a ascensão do imperador, haviam atacado o templo da Fortuna. Em represália, Juliano decide eliminar Cesareia do catálogo de cidades, privando-a inclusive do próprio nome, obtido sob o governo de Cláudio, como nos relata Sozomeno (Historia Ecclesiastica, V, 4). ${ }^{8}$ Visando a punir Antioquia pela maneira desrespeitosa com a qual foi tratado, Juliano nomeia Alexandre de Heliópolis, uma personagem sabidamente irascível e cruel, como consularis da Síria, estimando que este seria o governador apropriado para uma cidade rebelde. Além disso, declara abertamente a sua intenção de não mais retornar à cidade após o término da campanha da Pérsia, optando por instalar-se em Tarso, na Cilícia (Am. Marc., XXIII, 2, 3-4). O anúncio dessas medidas causou, naturalmente, profundo embaraço aos membros da boulé e ao restante da população, que acompanhou o imperador até as portas da cidade com votos de sucesso na guerra, desejando também que, num futuro próximo, Juliano fosse mais tolerante e compassivo com Antioquia, súplicas que não o comoveram. Devido à irritação evidente do imperador, uma comissão de notáveis, dentre os quais contava-se Libânio, dispõe-se a seguir a comitiva imperial, na expectativa de obter uma audiência de conciliação.

\footnotetext{
${ }^{8}$ Libânio, em sua Oratio XVI (14-15), descreve o tratamento dispensado por Juliano a Cesareia nos seguintes termos: “Olhem o que aconteceu na Capadócia. Aí uma famosa e próspera cidade, que praticava a eloquência e tinha sido sempre uma residência imperial de inverno, foi apagada da lista de cidades, já que supunha-se que sua conduta fosse muito indisciplinada para a sua posição". A despeito da imagem de filósofo assumida por Juliano, o que inclusive foi um dos motivos de atrito com os antioquenos, importa mencionar que o comportamento do imperador estava longe do ideal de rei-filósofo outrora formulado por Platão. Como demonstra Sidwell (2008), na narrativa de Amiano Marcelino, as referências à ira do imperador, um antigo tópos da literatura imperial, são mais frequentes sob o governo de Juliano, o que não deixa de ser, em certa medida, uma constatação surpreendente.
} 
No meio do caminho, vencido pela fadiga e pelos perigos da estrada, o sofista decide retornar. Os demais, no entanto, prosseguem até Litarba, um posto avançado na rota que conduzia a Bereia, onde finalmente são admitidos na presença de Juliano, embora sem conseguir demovê-lo da sua decisão de não mais regressar a Antioquia (Pellizari, 2015: 79). Nos meses seguintes, coube a Libânio a tarefa de intervir no imbróglio mediante duas orações, uma endereçada aos seus concidadãos (Or. XVI) e outra a Juliano (Or. XV), nas quais, por um lado, censura a população de Antioquia por mau comportamento e, por outro, suplica ao imperador o perdão para a cidade.

A intervenção de Libânio adquire singular relevância devido à posição da qual o sofista passou a desfrutar após o reencontro com o imperador. Embora Libânio seja, com toda justeza, incluído no rol dos amigos e partidários mais leais de Juliano, cabe salientar que o vínculo de amizade entre ambos era um acontecimento recente. Na época de juventude, em Constantinopla, Juliano encontrava-se vinculado a Hecebólio, um professor cristão. Por esse motivo, quando da sua passagem por Nicomédia, teria sido proibido pelo mestre de frequentar a classe de Libânio, convidado a ensinar na cidade após uma experiência profissional mal sucedida em Constantinopla. A despeito da proibição, Juliano, um admirador confesso do estilo de Libânio, acompanhava as lições deste último indiretamente, por intermédio de um mensageiro que todos os dias lhe reportava aquilo que o sofista havia ensinado, de maneira que, não por acaso, as primeiras orações compostas por Juliano conservam muitas semelhanças formais com as de Libânio (Cribiore, 2007: 142). Um primeiro encontro entre ambos teria ocorrido em 348 ou 349, em Nicomédia. Após essa data, não voltariam mais a estar juntos até que os caprichos da política imperial trataram de reaproximá-los. Em 362, quando Juliano adentrou Constantinopla, já na condição de Augusto, Libânio recebeu um convite da corte para fazer parte da embaixada que ofertaria o aurum coronarium ao novo imperador em nome de Antioquia. Temendo não ser bem recebido, resolve declinar do convite. Ao que parece, a recusa teria sido motivada pelo fato de o sofista, no elogio fúnebre que compôs em homenagem a seu tio, Fasgânio, tecer duras críticas a Galo, irmão de Juliano, executado por traição sob o governo de Constâncio II. Todavia, em julho de 362, por ocasião da chegada de Juliano e de sua comitiva à fronteira da Síria, Libânio é um dos integrantes da embaixada enviada para recepcioná-los. À primeira vista, fustigado pela idade e pela doença, não teria sido reconhecido. Coube ao tio de Juliano, o comes Orienti do mesmo nome, alertar o sobrinho sobre a presença do sofista. Comovido por revê-lo, o imperador lhe teria então dispensado uma calorosa acolhida (Pellizari, 2015: 71). 
A partir desse momento, Libânio passa a frequentar a corte, sendo convidado a pronunciar, em nome de Antioquia, um panegírico de boasvindas ao novo imperador (Or. XIII). O elogio, ao que parece, não obteve a repercussão esperada, muito provavelmente devido à má vontade de alguns cortesãos, a exemplo de Nicocles, Temístio de Bizâncio e Máximo de Éfeso (Wiemer, 2014: 203). Ciente da oposição que sofria, Libânio opta por se afastar, evitando inclusive participar dos sacrifícios praticados à profusão pelo imperador. A situação começa a mudar devido à intervenção de Prisco, um filósofo neoplatônico que, em agosto de 362, reintroduz Libânio na corte. Doravante, até a partida de Juliano, em 5 março de 363, o sofista se converte numa das personagens mais influentes do governo, observando-se um claro influxo no conteúdo de seus escritos, nos quais defende com veemência a proposta de reforma religiosa de Juliano, enaltecendo-o como o imperador ideal por respeitar a paideia e os cultos ancestrais (Pelizzari, 2015: 73-74). Em 1 de janeiro de 363, diante de uma plateia composta por altos dignitários, incluindo membros do Senado de Roma e de Constantinopla, Libânio é convidado a pronunciar outro panegírico, desta vez em louvor ao consulado de Juliano (Or. XII). Nessa oração, cria a imagem de um imperador-sacerdote responsável por oferecer pessoalmente sacrifícios diários aos deuses, exaltando Juliano como um amante da filosofia cujo principal intento era restaurar os ritos próprios do helenismo, que teriam sido negligenciados ou mesmo proibidos (Wiemer, 2014: 204).

No início de 363, Libânio já era reconhecido por possuir livre acesso aos círculos do poder imperial, razão pela qual, diante da polêmica envolvendo Juliano e a população de Antioquia, é chamado a interceder em favor da pólis, o que é feito, como dissemos, por intermédio de duas orações, a Oratio XVI, Aos antioquenos, sobre a ira do imperador; e a Oratio $\mathrm{XV}$, Embaixada a Juliano. Embora, no corpus de discursos de Libânio, a Oratio XVI figure após a XV, estima-se que a sua redação seja anterior, tendo sido escrita cerca de um mês após a partida de Juliano, isto é, na primeira quinzena de abril. Nos meses seguintes, Libânio se dedicou à redação da Oratio $\mathrm{XV}$, dita Presbeutikós, inicialmente projetada como um elogio à esperada vitória contra os persas. Ao que tudo leva a crer, ambas as orações nunca foram declamadas oficialmente, sendo conhecidas apenas por aqueles mais próximos do autor, ou seja, seus alunos, amigos e familiares (Van Hoof; Van Nuffelen, 2011: 181). Em ambos os discursos, Libânio se esforça por atender ao apelo dos seus concidadãos para que intercedesse em favor de Antioquia, tendo em vista o profundo descontentamento de Juliano, como manifesto sem subterfúgios no Misopógon. A estratégia de defesa adotada pelo sofista não é, no entanto, a de inocentar a cidade de qualquer ofensa contra a majestade imperial, 
mas antes a de admitir o caráter arrogante e indisciplinado dos antioquenos, a quem acusa de terem se portado muito mal. Os argumentos de Libânio reforçam, portanto, a concepção segundo a qual a população se encontrava sob o domínio da tryphé, ou seja, do prazer desenfreado proporcionado pela volúpia e pelos excessos de embriaguez, como já havia se queixado o próprio imperador (Saliou, 2011: 160-161). Muito embora Libânio admita a interferência de fatores de ordem econômica para a deflagração do conflito, uma vez que os mais ricos teriam deixado de abastecer o mercado a fim de especular com os gêneros alimentícios (Or. XVI, 21), a afronta mais séria segundo ele teria sido a atitude desrespeitosa da população para com um soberano justo e piedoso, sem que ninguém tivesse se levantado em sua defesa. De acordo com Libânio,

O que perturbou o imperador é que alguns dentre seus súditos estivessem imbuídos de tanta insubordinação e desrespeito, e não tivessem escrúpulos em atentar contra a dignidade imperial, o que eles não ousariam nem mesmo sob um regime democrático, que permite uma licença além do recomendável. Quando tais libelos difamatórios (asmata) circulavam em nossa cidade, quem protestou contra tal impiedade? Quem sentiu algum pesar? Quem disse a seu vizinho: "Venha, vamos detê-los, prendê-los, executá-los"? [...] Nós deveríamos ter sido aqueles que reclamavam a punição, e tais malfeitores deveriam ter sido executados antes mesmo que ele [i. é, Juliano] ouvisse tais atrocidades. "Mas", objeta-se, "eles eram apenas um punhado". Então mais uma razão para punilos. [...]. "Mas eles eram homens desonestos, mendigos, criminosos, assaltantes". Vocês acrescentaram outra razão pela qual esta claque deveria ter sido combatida. [...] "Aqueles que circulavam tais histórias não eram nossos cidadãos", me dizem. Então a má conduta deles reside no que disseram, a nossa em tê-lo permitido. Se vocês podem evitar algo e se recusam a fazê-lo, isso é equivalente a agir: se vocês não se irritam com malfeitores, vocês aprovam o malfeito. [...] Que desculpa se poderia dar por não se ter agido assim? Vocês me dizem, "nós tínhamos receio de que se tentássemos deter algo que era aceito como prática religiosa, nós seríamos acusados de abolir o festival". [...] Eu concordo que o ridículo faça parte de alguns festivais, desde que seja moderado e não seja proferido por bocas sem freio, pois ele não é dirigido contra os iguais. [...] Se aos meus escravos fosse permitido abusar de mim sem restrição, usando o feriado como desculpa, eu nunca teria reconhecido os deuses aos quais agrada tal atenção. Desse modo, homens que têm alguma consideração pela sua cidade já deveriam ter suprimido esse tipo de coisa há muito tempo, e eles nunca deveriam ter ignorado os insultos dirigidos nem mesmo contra o indolente Constâncio. Eles deveriam considerar que, embora um imperador seja fraco de caráter, sua posição ao menos merece respeito (Or. XVI, 28-38).

Libânio se refere aqui aos gracejos que circulavam pelas ruas de Antioquia contra Juliano, em especial aqueles proferidos no contexto do festival das Calendas, marcado pela inversão da ordem social e pela crítica mordaz contra as autoridades públicas. No início daquele ano de 
363, o principal objeto da ironia dos antioquenos teriam sido as medidas adotadas pelo imperador, não apenas as de natureza econômica, como o tabelamento de preços, mas principalmente as de natureza religiosa, pois Juliano, como assinalamos, nutria o desejo de fazer de Antioquia o emblema da sua revitalização do paganismo e, mais do que isso, em convertê-la numa hiera pólis, numa cidade santa devotada inteiramente aos deuses, o que implicava, em contrapartida, a renúncia à tryphé, vale dizer, às festas, aos jogos e aos entretenimentos que conformavam a identidade dos habitantes, como discutimos em artigo recente (Silva, 2015). Para Libânio, a população teria exorbitado do seu direito de protestar, pois as ofensas atentavam contra a majestade do imperador, algo que não poderia ser tolerado nem mesmo sob um governo considerado por todos injusto, como o de Constâncio II. A despeito das tentativas dos habitantes de se eximirem da acusação, atribuindo a culpa a uma trupe de baderneiros e malfeitores, Libânio é inflexível em condenar o comportamento de toda a cidade, que não poderia ter sido conivente com a situação, nem mesmo sob a justificativa de preservar a sacralidade dos festivais. Nesse ponto, se coloca numa posição que desafia até mesmo as tradições do helenismo, pois recusa-se a reconhecer que um pretexto religioso qualquer possa ser invocado como justificativa para a insolência contra um imperador que "é diferente dos deuses apenas pelo fato de ingerir a comida dos homens" (Or. XVI, 18). Para ele, a condição divina do basileus se sobrepõe aos hábitos e costumes cultivados pela pólis, cujo modus vivendi deve ser completamente reformado a fim de merecer a clemência do imperador, como vemos na seguinte passagem, na qual instrui os antioquenos sobre como aplacar a ira de Juliano:

Qual então seria a cura [para os problemas de Antioquia]? Nos apresentarmos realmente arrependidos e pesarosos. Apresentemos nossa súplica de modo contrito e com decoro. De fato, é uma das acusações que pesam contra nós que exibimos mais arrogância do que deveríamos e que nada pode alarmar nossa cidade [...]. Deixemos que a cidade assuma um ar de aflição comum e que imite uma casa de família em sua tristeza. Fechemos nossos teatros por um intervalo de tempo, peçamos aos dançarinos e atores que deixem nossos vizinhos repartir conosco as alegrias que proporcionam e passemos o verão sem entretenimentos. Reduzamos o número das corridas de carro. Façamos seis em lugar de dezesseis. Esse extravagante sistema de iluminação, esse sinal de indolente luxúria dependurado nas entradas das termas, vamos reduzi-lo a uma fração do que se tem agora. Apliquemos a sentença a nós mesmos, com receio de que o imperador o faça. [...] Mesmo que os adeptos do teatro reclamem, façamos com que reconheçam a seriedade da situação e não levemos em consideração a opinião dos que desaprovam isso. Seria desastroso favorecêlos em detrimento da comunidade inteira, e ter mais cuidado em divertir aqueles que reconhecidamente não podem suportar a existência sem os seus ídolos do palco que em apaziguar a ira do imperador [...] (Or. XVI, 40-45). 
O que Libânio advoga é uma mudança completa no estilo de vida da população, que deveria reduzir, senão abandonar, as competições no hipódromo e os espetáculos teatrais que tanto apreciava. Libânio se refere também à existência de um dispendioso sistema de iluminação pública que, acredita, favorece o desregramento, opondo-se assim a uma das mais singulares características de Antioquia: a intensidade da sua vida noturna, pois, ao contrário da maioria das cidades antigas, as imediações da avenida das colunatas, do Fórum de Valente e da ágora de Epifânia eram iluminadas à noite, serviço a cargo de um supervisor denominado epimeletes, responsável por arrecadar dos comerciantes o combustível necessário para garantir o funcionamento do sistema. Antioquia era assim famosa por manter-se ativa dia e noite, traço que Libânio já havia destacado, embora de forma elogiosa, no Antiochikos (267), um panegírico à cidade pronunciado em 356. Nos primeiros meses de 363, no entanto, a conjuntura era outra, pois Antioquia se encontrava imersa numa crise sem precedentes, fruto, segundo Libânio, da impetuosidade e arrogância da população, que preferiu voltar as costas a Juliano, um imperador amante da filosofia e da paideia cuja única falta teria sido pretender, por todos os meios possíveis, coibir os excessos da cidade a fim de elevá-la moralmente. Como expiação diante da falta cometida, Libânio recomenda aos seus compatriotas a contrição, o decoro e o recolhimento, ou seja, que se comportem exatamente da maneira desejada por Juliano, um líder capaz de resgatar Antioquia das armadilhas da tryphé, fortalecida sob o governo de Constâncio II. Dirigindo-se ao imperador na Oratio XV, discurso no qual se apresenta como porta-voz de Antioquia, argumenta o sofista:

O que me surpreende é que você [i. é, Juliano] esteja surpreso por alguma desordem nas cidades após a longa experiência delas sob um mau professor [i. é, Constâncio]. Não estava tudo repleto de confusão, incompetência e negligência? Não era a lei letra morta e cargos públicos vendidos e comprados. [...]? A virtude estava fora de moda sob um reinado de prazer e criminosos eram capazes de escapar ilesos. Desse modo, qual a surpresa se, sob estas rédeas livres para a fraqueza, a conduta das cidades seja de algum modo maculada em alguns momentos? Se alunos de maus professores não têm esperança de se tornarem habilidosos na eloquência, pode o mundo reter alguma decência quando um indolente se encontra no trono? Se rebanhos são arruinados pela estupidez de seus pastores, são as cidades bem ensinadas pela incompetência dos imperadores? Por que agora podemos considerar o mundo feliz? Porque um médico experiente apareceu para assisti-lo. Nós estamos felizes, pois ele irá mudar o comportamento das cidades e melhorá-las. [...] Nos dias fáceis do passado, vivemos todos uma vida de indisciplina. Agora estamos sob um jugo mais firme, e devemos tentar suportá-lo. Perdoe nossas pequenas faltas e nos melhore, de maneira que não tenhamos necessidade de perdão (Or. $\mathrm{XV}, 67-70)$. 
Libânio supõe assim a existência de um paralelismo ético entre os soberanos e as cidades. Em sua opinião, os excessos cometidos pelos habitantes de Antioquia se deveram, em larga medida, aos descaminhos do governo de Constâncio II, tido como um mau professor em virtude da sua incapacidade em conter a incompetência e a venalidade dos agentes públicos, o que culminou no mau comportamento de toda a população, entregue à frivolidade e à indisciplina. Desse ponto de vista, Antioquia poderia e deveria ser perdoada, pois ela teria sido, de certa forma, contaminada pela falta de caráter do próprio imperador, ainda que Libânio, em momento algum, advogue pela inocência da cidade. Importava, no entanto, reconhecer que os tempos haviam mudado, pois contra a moléstia que corrompia o Império despontava agora Juliano, saudado como o médico das cidades. Considerando que o propósito do imperador era sanar a enfermidade moral de Antioquia, devolvendo-lhe a saúde, Libânio defende sua autoridade para intervir no movimento da vida urbana. Juliano, no entanto, não seria capaz tão somente de restituir à cidade uma condição ótima vivida no passado, mas também de aperfeiçoá-la. A essa altura valeria a pena nos indagarmos acerca do que consistiria isso. Tendo em vista as medidas tomadas por Juliano em âmbito religioso, nos parece que o aperfeiçoamento de Antioquia não se restringisse ao reforço ou revitalização do helenismo, mas incluísse uma proposta muito mais ambiciosa: a reforma da pólis, a sua conversão numa cidade pia e santa, ou seja, numa cidade devotada ao ascetismo e ao culto dos deuses, motivo pelo qual as manifestações ordinárias da vida cívica, tais como os jogos, festivais e espetáculos deveriam ser redimensionados conforme os novos parâmetros ético-religiosos que o imperador buscava estabelecer.

Nesse aspecto, Libânio se mostra sem dúvida solidário com as aspirações de Juliano. Esclarecendo aos habitantes de Antioquia como poderiam se reconciliar com o imperador, afirma: "não é se prostrando no chão, suplicando com ramos de oliveira, apresentando coroas, protestos e embaixadas, nem enviando um orador experiente que vocês aplacarão a ira do imperador, a menos que vocês parem com o presente absurdo e entreguem sua cidade a Zeus e aos outros deuses" (Or. XVI, 46). Aqui, a "entrega da cidade a Zeus e aos outros deuses" não significa o abandono do cristianismo e o retorno ao paganismo, pois, ao contrário do que supõem alguns autores, ${ }^{9}$ não é possível afirmar que, em meados do

\footnotetext{
9 A suposição segundo a qual Antioquia, à época de Juliano, fosse já uma pólis majoritariamente cristã é sustentada por autores como Bowersock (1997: 105); Ballabriga (2009: 66); e Pellizzari (2015: 79). Cumpre notar, entretanto, que a tendência contemporânea da historiografia é a de refutar tal interpretação devido ao fato de que,
} 
século IV, Antioquia já fosse cristã. Quanto a isso, basta apenas recordar que a entrada de Juliano na cidade ocorreu exatamente num dia em que se celebrava o festival de Adônis. A "entrega da cidade" aos deuses parece sugerir uma mudança de atitude na maneira como os indivíduos exerciam a sua devoção, mudança consubstanciada na adesão aos sacrifícios, na observância do ascetismo, no abandono das festas e demais entretenimentos e na assiduidade aos templos, práticas das quais o imperador era adepto e que desejava estender a toda a população. Segundo Soler (2006: 64), a reação de Antioquia à tentativa de reforma religiosa de Juliano "é um fenômeno de massa complexo no centro do qual se encontra a exuberância festiva, os aspectos dionisíacos da cidade, que o imperador desprezou". Não que a cidade fosse ímpia ou indiferente para com os deuses, e muito menos ingrata para com um imperador bem intencionado. ${ }^{10}$ Na realidade, Antioquia não se adequava aos novos padrões que Juliano tentava impor a ela, recorrendo aos mecanismos habituais de expressão, ou seja, à ironia, à irreverência e à ocupação ostensiva das ruas com o propósito de resistir a qualquer tentativa de enquadramento autoritário do seu cotidiano. Evidência suplementar sobre o quanto a atuação de Juliano foi desagradável para os antioquenos nos é fornecida por Teodoreto de Ciro, em sua História Eclesiástica (III, 20), ao afirmar que, quando a notícia da morte do imperador alcançou Antioquia, a multidão, tomada de intensa alegria, comemorou nas igrejas, nos martyria e no teatro. Em seu epistolário, Libânio, ele mesmo, recorda que, à época, os antioquenos não hesitaram em invadir as ruas com seus cortejos festivos (Ep. 1220, 2 apud Soler, 2006: 58). Tal comportamento não pode ser tomado a priori como insensato, cruel ou desrespeitoso, pois, como sustenta Julia (1998: 229), mesmo a estranheza emanada das mais perturbadoras situações envolvendo amplos coletivos revela, ao fim e ao cabo, as "perguntas que o corpo social formula a respeito da sua própria identidade, e os alarmes que se propõe a conjurar segundo seu léxico próprio". No caso de Antioquia, seus habitantes, confrontados por um imperador atormentado pela ideia de pureza e de elevação espiritual, buscaram reagir da maneira como podiam, ou seja, levando para a rua os seus komoi e choroi dionisíacos e fazendo do canto, da dança e do deboche instrumentos de defesa dos seus valores e tradições.

nos séculos IV e V, o helenismo e o judaísmo seguiam como forças culturais ativas dentro da cidade, repartindo com o cristianismo o território urbano.

$10 \mathrm{Na}$ opinião de Hawkins (2012: 172), Juliano teria sido ao fim e ao cabo um imperador incompreendido pela população de Antioquia. Para uma avaliação bem menos parcial acerca do episódio, consultar Van Hoof \& Van Nuffelen (2011). 


\section{Fontes antigas}

AMMIANUS MARCELLINUS. History. Translated by John C. Rolfe. Cambridge: Harvard University Press, 2006. v. 1.

JULIANO. Contra os galileos. Cartas y fragmentos. Testimonios. Leyes. Introducción, traducción y notas por José García Blanco \& Pilar Jiménez Gazapo. Madrid: Gredos, 1982.

JULIEN. Oeuvres complètes. Texte établi et traduit par Christina Lacombrade. Paris: Les Belles Lettres, 1964. t. II, 2e. partie.

LIBANIUS. The Antiochikos: in praise of Antioch. In: Antioch as a centre of Hellenic culture. Translated with an introduction by A. F. Norman. Liverpool: Liverpool University Press, 2000, p. 3-65.

LIBANIUS. The embassy to Julian. In: Selected orations. Edited and translated by A. F. Norman. Cambridge: Harvard University Press, 1969, p. 147-207. v. 1.

LIBANIUS. On the emperor's anger. In: Selected orations. Edited and translated by A. F. Norman. Cambridge: Harvard University Press, 1969, p. 209-249. v. 1.

PHARR, C. \& DAVIDSON, T. S. (Trad.) Codex Theodosianus and novels and Sirmondian Constitutions. Princeton: Princeton University Press, 1952.

SOZOMENUS. The Ecclesiastical History. In: SCHAFF, P.; WACE, H. (Ed.). Nicene and post-Nicene fathers. Text translated by Chester D. Hartranfty. Peabody: Hendrickson, 2004, p. 181-427.

THEODORET. The Ecclesiastical History. In: SCHAFF, P.; WACE, H. (Ed.). Nicene and post-Nicene fathers. Text translated by Blomfield Jackson. Peabody: Hendrickson, 2004, p. 33-159.

\section{Referências bibliográficas}

BALLABRIGA, A. L'empereur Julien et la licence festive. Pallas, n. 81, p. 65-81, 2009.

BOWERSOCK, G. W. Julian, the Apostate. Cambridge: Harvard University Press, 1997. 
CRIBIORE, R. The school of Libanius in Late Antique Antioch. Princeton: Princeton University Press, 2007.

CROGIEZ, S. Échanges écrits dans la rue: affiches, tracts and graffiti à Rome et à Pompéi. In: LEMÉNOREL, A. (Éd.) La rue, lieu de sociabilité? Rouen: Université de Rouen, 1997, p. 225-232.

DOWNEY, G. A history of Antioch in Syria. Princeton: Princeton University Press, 1961.

FARGE, A. Lugares para a História. Belo Horizonte: Autêntica, 2011.

FUNARI, P. P. A vida quotidiana na Roma antiga. São Paulo: Annablume, 2003.

GLEASON, M. W. Festive Satire: Julian's Misopogon and the New Year at Antioch. The Journal of Roman Studies, n. 76, p. 106-119, 1986.

HAWKINS, T. Jester for a day, Master for a year : Julian's Misopogon and the Kalends of 363 CE. Archiv für Religionsgeschichte, v. 13, 1, p. 161-173, 2012 .

JULIA, D. A violência das multidões: é possível elucidar o desumano. In; BOUTIER, J.; JULIA, D. (Org.). Passados recompostos: campos e canteiros da História. Rio de Janeiro: Editora da UFRJ, 1998, p. 217-229.

KLEINMAN, B. The crisis at Antioch under Julian the Apostate. Hirundo, bd. 7, p. 67-76, 2008-2009.

LEGUAY, J. P. La rue, lieu de sociabilité. In: LEMÉNOREL, A. (Éd.) La rue, lieu de sociabilité? Rouen: Université de Rouen, 1997, p. 11-29.

LIEBESCHUETZ, J. H. W. G. Antioch, city and imperial administration in the Later Roman Empire. Oxford: Clarendon Press, 1972.

LIMA NETO, B. M. Entre a filosofia e a magia: o caso da estigmatização de Apuleio na África romana (séc. II d. C.). Curitiba: Prismas, 2016.

MAYER, W. The topography of Antioch described in the writings of John Chrysostom. In: SALIOU, C. et al. (Ed.). Les sources de l'histoire du paysage urbain d'Antioche sur l'Oronte. Paris: Université Paris 8, 2012, p. 81-100.

PELLIZZARI, A. Testimonianze di un'amicizia: il carteggio fra Libanio e Giuliano. In: MARCONE, A. (Ed.). L'imperatore Giuliano: realtà storica e rappresentazione. Milano: Mondadori, 2015, p. 65-86. 
PETIT, P. Libanius et la vie municipale a Antioche au IVe siècle aprés J.-C. Paris: Paul Geuthner, 1955.

SALIOU, C. Jouir sans entraves? La notion de tryphè dans l'Éloge d'Antioche de Libanios. In: LAGACHERIE, O.; MALOSSE, P. L. (Éd.). Libanios, le premier humaniste. Alessandria: Edizioni dell'Orso, 2011, p. 153165.

SALIOU, C. Le palais impérial d'Antioche et son contexte à l'époque de Julien. Antiquité Tardive, n. 17, p. 235-220, 2009.

SALIOU, C. Mesurer le paradis: contribution au portrait d'Antioche aux époques romaine et protobyzantine. In: NICOLET, C.; ILBERT, R.; DEPAULE, J. Ch. (Dir.). Mégapoles méditerraanéennes: géographie urbaine rétrospective. Paris: École Française de Rome, 2000, p. 802-819.

SIDWELL, B. Ammianus Marcellinus and the anger of Julian. Iris, Journal of Classical Association of Victoria, v. 21, p. 56-75, 2008.

SILVA, G. V. Juliano e a imagem de Antioquia no Misopogon. In: SILVA, G. V.; SILVA; E. C. M. (Org.). Fronteiras e identidades no Império Romano. Vitória: GM Editora, 2015, p. 119-140.

SILVA, G. V. A sinagoga como espaço de sociabilidade entre cristãos e judeus em Antioquia. In: QUADROS, E. G.; SILVA, M. C. (Org.). Sociabilidades religiosas: mitos, ritos e identidades. São Paulo: Paulinas, 2011, p. 33-52.

SOLER, E. Sacralité et partage du temps et de l'espace festifs à Antioche au IVe siècle. In: REBILLARD, É.; SOTINEL, C. (Éd.). Les frontiers $d u$ profane dans l'Antiquité tardive. Paris: De Boccard, 2010, p. 273-286.

SOLER, E. Le sacré et le salut à Antioche au IVe siècle après J.-C.: pratiques festives et comportements religieux dans le processus de christianisation de la cité. Beyrouth: Institut Français du Proche-Orient, 2006.

SOLER, E. La rue à Antioche au IVe siècle après J.-C.: entre kômoi et pompai, les cortèges festifs comme reflet de la sociabilité. In: LEMÉNOREL, A. (Ed.). La rue, lieu de sociabilité. Rouen: Université de Rouen, 1997, p. 325-330.

VAN HOOF, L; VAN NUFFELEN, P. Monarchy and Mass Communication. Antioch 362/363 revisited. The Journal of Roman Studies, 101, p. 166-184, 2011. 
WIEMER, H. U. Emperors and empire in Libanius. In: VAN HOOF, L. (Ed.). Libanius: a critical introduction. Cambridge: Cambridge University Press, 2014, p. 187-219.

WINTERLING, A. Politics and society in imperial Rome. Oxford: WileyBlackwell, 2009. 